\title{
Insisting on Action in Education: Students are Unique but not Irreplaceable
}

\author{
Liesbeth Noordegraaf-Eelens ${ }^{1,2,3} \cdot$ Julien Kloeg ${ }^{4}$
}

Published online: 13 March 2020

(c) The Author(s) 2020

\begin{abstract}
Biesta distinguishes three functions of education: qualification, socialization and subjectification. We focus on subjectification. When first addressing this concept, Biesta referred to action as defined by Arendt, thereby stressing the importance of 'the question of freedom'. More recently, the question of freedom (Arendt) is replaced by 'the question of responsibility' (Levinas). For Levinas responsibility is related to irreplaceability. While the concept of responsibility is valuable, we question the call upon irreplaceability in education. Actively taking responsibility where irreplaceability might not be either present or felt should be central to education. Unlike the morally clear examples invoked by Biesta, complex societal issues like the climate and refugee crisis are not accessible as an immediate appeal to a specific subject. Therefore, we propose a return to Arendt and her concept of action. Action allows and requires students to create the world anew, to take a position without pretending that the outcome can be controlled. Biesta refers to this as the impossibility of education. However, rather than repeating the theme of impossibility, we focus on the possibilities of education: there are several ways to create the world anew.
\end{abstract}

Keywords Philosophy of education · Biesta $\cdot$ Arendt $\cdot$ Levinas $\cdot$ Subjectification · Unicity Irreplacibility $\cdot$ Responsibility $\cdot$ Shared world $\cdot$ Action $\cdot$ Natility $\cdot$ Climate and refugee crisis

Julien Kloeg

kloeg@euc.eur.nl

Liesbeth Noordegraaf-Eelens

noordegraaf@esphil.eur.nl

1 Erasmus School of Philosophy, Erasmus University Rotterdam, Rotterdam, The Netherlands

2 Codarts Rotterdam, Rotterdam, The Netherlands

3 Rotterdam Arts and Sciences Lab, Rotterdam, The Netherlands

4 Erasmus University College, Rotterdam, The Netherlands 


\section{Introduction}

Recognizing and emphasizing the possibilities of the subject beyond the structure of society (for instance, with a view to transforming society) has long been a focal point of critical traditions within the philosophy of education. A promising and influential concept that intends to capture this recognition and emphasis is subjectification, as understood by the educational theorist Gert Biesta, as one of the three functions of education (next to qualification and socialization). Subjectification involves the "subjectivity of the human person" in excess of the given social order into which they are inserted (Biesta 2012, 13). This concept at the same time exposes a challenge facing progressive or critical education both in theory and in practice. Subjectivity has often been cast as the starting point for transforming society, but in such a way that the outcome of the transformation is already determined in important respects. An early example from critical philosophy of education is the pioneering work of Paolo Freire. His 'pedagogy of the oppressed' is grounded in a critique of socio-economic inequalities. Through education students become aware of these inequalities and develop the tools to oppose them. By letting students experience that they are entangled in power structures, they gain the ability to free themselves as well as society from these power structures. Biesta contests exactly this structural feature of critical pedagogies. In his analysis, critical pedagogies such as those espoused by Freire and his followers reduce education and subjectivity to an instrumental function in an already-determined transformation of society (Biesta 1998).

More generally speaking, Biesta utilizes two sites of tension to mount a convincing critique of the 'impossible' goals of traditional critical education: first, the nature of education and, second, human subjectivity as such. Rereferring to the work of Hannah Arendt, Biesta relates subjectivity to freedom, uniqueness (or natality) and unpredictability. Society can be created anew. However, what it will look like afterwards is impossible to know in advance: it is not known and cannot be known. For this reason education is not in the business of producing a predetermined goal, set in advance; hence the 'impossibility' of education.

Throughout his work Biesta repeatedly addresses this theme of impossibility. However, he has moved from an early line of argument based on Hannah Arendt's concept of action (Biesta 1998) and the "question of freedom" to one based on the work of Emmanuel Levinas and his concept of responsibility (see Biesta 2017, 12). Arendt is still mentioned with approval when it comes to the overall goal of education, but also criticized, in particular because she focuses on interindividual difference and does not give quite enough 'space' to uniqueness; therefore, Biesta moves on to subjectivity as defined by Levinas, in terms of irreplacibility. Irreplaceability is uniqueness that is called upon by others, where this call is addressed to a specific subject. Biesta uses the example introduced by Alphonso Lingis (1994) of a dying friend who asks for our company. It is clear that this request can only be fulfilled by the person who is called upon. Using this Levinasian approach ultimately leads Biesta to argue for a "pedagogy of empty hands" (2008). In this article we question this move to and specially the role of irreplaceability in education.

It is far from self-evident that irreplaceability should be central to educational theory and practice. Complex societal problems, such as the climate or refugee crisis, do not make a distinction between persons: it does not matter who addresses these complex issues as long as they are addressed. Hence, they address us all qua human beings, and in that sense equally. Education is also about showing students the importance of creating the world anew, even —or especially — when they are replaceable. We argue for a return to Arendt 
because her account of human subjectivity is a valuable resource for the theory and practice of education. Arendt develops her own concept of uniqueness in relation to our shared world; at the same time, human subjectivity is not something that is called upon by others. Instead, it is created through action. In Arendt's work we find resources that point out the dependence of action on an institutional "space of appearance" (Benhabib 2018, 110) and a shared world (Noordegraaf-Eelens et al. 2019) as well as on conditions of plurality and equality (Arendt 1998, 7-9). All of these seem to us to be important elements that educational theory and practice should address.

In the sections that follow, we first elaborate on Biesta's ideas regarding subjectification. After that we outline his shift from Arendt to Levinas. We criticize the overly 'subjective' orientation of an educational theory and practice based on a Levinasian ethics of responsibility rooted in irreplaceability, which for that reason does not include an essential connection to our shared world. In arguing for a return to Arendt, we do not here address the dimension of plurality and equality that is part of her account of action, instead staying within the parameters of Biesta's move from Arendt to Levinas. In conclusion, we offer vistas on the type of educational practice that follows from our use of Arendt. After all, Biesta's use of Levinas is of great importance to his proposed 'pedagogy of interruption' (Biesta 2015a, Ch4; cf. Biesta 2017, 16-20) and granting Arendt more prominence will determine not only how we conceptualize education, but also how we do education.

\section{Subjectification, Arendt and the Impossibility of Education}

\section{Subjectification}

Subjectification is introduced by Biesta as part of a non-separable triad formed together with qualification and socialization (Biesta 2008, 2012, 2019). Qualification entails equipping students with "knowledge, skills, and dispositions", which as Biesta notes is taken by some to be the whole point of education (Biesta 2012,13). Socialisation refers to becoming "part of existing social, cultural and political practices and institutions" (ibid). This function, too, is explicitly acknowledged through the use of agendas and canons that politics bestows (or, alternatively, imposes) upon educational institutions in order to insert pupils and students into the existing order. The third and final part of Biesta's triad is subjectification, which he separates from socialization by referring the former not to inserting into or existence within existing orders, but about "how we can exist 'outside' of such orders, so to speak": of concern here is the "subjectivity of the human person" (ibid).

In summary, we may say that whereas qualification and socialization are about the insertion of newcomers into an existing (professional and societal) order, subjectification concerns the newcomer insofar as she exceeds existing orders. Biesta criticizes an exclusive focus on socialization and/or qualification. According to him education should be a balancing act between all three functions (Biesta 2012), to such an extent that they are continuous with each other ("not separate") and his own distinction is primarily analytic in nature (Biesta 2019, 15). In this article our focus is on subjectivity and subjectification; in particular, we ask how to align them with the nature of education and how to involve it within educational theory and practice. 


\section{Arendt's Place in the Argument}

For Biesta subjectification expresses the relationship between subjectivity and education. In his earlier work this is based upon Arendt's concept of natality, which stresses the freedom of the individual. Education should offer a place where uniqueness and freedom can flourish. In Arendt's own words: "natality is the essence of education" (Arendt 1961, 174). Every newcomer brings something new into the world that cannot be anticipated. These categories of natality and the new are present in all human activity but only action realizes them fully (Arendt 1998, 9). Action is understood as individual initiative which inserts man into the world, and thereby renews the world (ibid, 176-177).

Arendt's view on subjectivity aligns with Biesta's proposal that education should provide room to human beings who are capable of their own actions (Biesta 2012) rather than striving to attain outcomes set by others. The pre-determinedness that can be found in critical pedagogies leaves no room for action as formulated by Arendt: repurposing one of her formulations, it "strikes from the newcomers' hands their own chance at the new" (Arendt 1961, 177).

The type of education that both Arendt and Biesta envision is risky, as it is not possible to predict what the outcome will be. This is what Biesta calls the impossibility of education (Biesta 1998), in the sense that its success can never be guaranteed. The connection Arendt establishes between education and natality usefully brings this out. In a similar vein, Biesta has discussed the "beautiful risk of education" in more recent work (2015b).

\section{From Action to Responsibility}

While Biesta's criticism itself has remained consistent over the years, his mode of questioning has itself shifted in form: this shift is our central concern in this paper. Biesta sees the shift as the outcome of his break with the philosophy of the subject; in Levinas, he finds the means to shift to an "ethics of responsibility" instead (Biesta 2008). In particular, Biesta finds that there are two related limitations associated with a reliance on Arendt that Levinas is in a better position to address. First, Arendt provides what he calls a "thirdperson" perspective on subjectivity. This implies that unicity is only a theoretical category for Arendt; she does not make clear when or how it matters that $I$ am unique. Second, she presents a "general account of the condition of human subject-ness rather than an account of each human subject in its uniqueness" (Biesta 2017, 11; emphases in original). In other words, Arendt's use of unicity as a general description is only able to address existing as $a$ subject, some subject—subjectivity in general, tarring all subjects with the same brushbut precisely not existing as this subject. Levinas, according to Biesta, is able to provide a first-person perspective on subjectivity precisely by describing the individual subject in terms of his or her unicity as a matter of irreplaceability (ibid, 31, 33). We will explain this Levinasian mode of subjectivity in the next section. Biesta's change of heart concerning subjectivity has consequences for how he can define education. Extending this point, we will question whether Biesta can stick to the impossibility of education while also making such central use of Levinas. Does this form of subjectivity still leave room for subjectification? 


\section{Redefining Subjectivity}

The Levinasian critique aimed against a third-person theory of subjectivity (which becomes Biesta's charge against Arendt) is that it grows out of a humanism-"a truth about the human"-against the background of a societal crisis of humanism, which over the course of the twentieth century has been revealed as "not sufficiently human" (Biesta 2008, 200-201). Levinas notes two main problems with humanism. First, in positing a norm of the human in the first place, those who do not meet this norm are excluded, to the point of literally being exterminated (ibid, 202). Second, humanism is unable to define human beings beyond seeing them as variations of its own predetermined essence: Biesta here explicitly says that humanism can only think in terms of socialization (ibid).

Levinas, as remarked, enables Biesta to move from a third-person theory of subjectivity to an ethics of responsibility which is necessarily first-person. For Levinas, "subjectivity should not be understood as issuing from one's own initiative" (ibid, 203, emphasis added). This means that responsibility should not be conceived as a relation consciously entered into or an act of an already full-formed ego or subject. There is thus no given essence or being for responsibility to latch onto. Rather, subjectivity is a "mode" "otherwise than being" (ibid, 204). The possibility for the subject to exist as a subject, that is, as an irreplaceable individual (the "I and no one else", Levinas $1998,14,126)$, only occurs when normal or 'immanent' existence is rudely interrupted (Biesta 2017, 13). Arendt, according to Biesta, correctly identifies the importance of action (also as something that is in a certain sense beyond our control), but is only able to think unicity as difference (that is, from a third-person perspective) and for that reason falls short of this Levinasian account of unicity as irreplaceability (ibid, 13-14).

We are now in a position to further consider the Lingis (1994) example, also recounted by Biesta $(2017,12)$. A dying friend would like to see me. In such a case I cannot ask a subject 'in general' to take my place: the request "singles me out" (Lingis 1986, 110). I cannot go on living my day-to-day life as if nothing had happened (my immanent existence is interrupted), nor can I delegate the call to someone else (I am unique as a specific subject). For Levinas, this constitutes the meaning of subjectivity: it is the external appeal on us (often captured through terms such as 'the face of the other') that creates responsibility as the "first reality of the self" (Bauman 1993, 13; Biesta 2008, 44).

From this Levinasian starting point, Biesta calls for "a pedagogy of empty hands" (2008) which does justice to Levinas' critique of humanism based on the importance of subjectivity. According to Biesta, Levinas shows that the uniqueness of the subject only acquires meaning at the moment when immanent existence is interrupted (ibid, 204). Since we do not have recourse to humanism's essences and goals imposed upon human existence, education needs to leave behind or hold back "all the 'tricks of the trade,' all the wisdom of the world, all national curricula and educational strategies, all recipes for 'what works,' in order to be able to approach newcomers without an agenda or preconception" (ibid, 208). In this sense the educator stands empty-handed. All she can do is ask the newcomer "what they are bringing into the world" (ibid). As Biesta notes, this is not, nor could it be, a recipe for the production of moral subjects. We can only ask: "What do you think of it?" (Biesta 1998, 2008; see also Rancière 1991). For Biesta, this question and education as such involves a responsibility for the subjectivity of the newcomer on the part of the educator, which constitutes an element of the type of educational relationship Biesta envisages (Biesta 2005, 63). 
Biesta's embrace of Levinas brings a couple of questions to the table that are related to the relationship between subjectification and education. The first one is whether an educational setting can be compared to the situation Biesta is describing using the Lingis example. It is to be expected that complex societal issues are discussed within education (without thereby instrumentalizing education). Such issues typically lack clarity with regard to the distribution of responsibilities, and with regard to who is or is not replaceable. Second, the position of Biesta and the example he provides are questionable when it comes to the impossibility of education. In the Lingis example it is to a large extent clear what should be done by a specific subject, who is irreplaceable in that sense. Wouldn't that mean that education by interruption implies a pre-determined future scenario?

\section{Insisting on Action and the Possibilities of Education}

The shift away from humanism is important for the purpose of education, since seeing newcomers as variations on a given human essence limits the renewal of the world to what the essence itself will allow. At the same time, we will argue in what follows that leaving Arendt behind and adopting a Levinasian ethics of responsibility instead overshoots the mark. Levinas is highly insightful in the sense that his work allows us to rethink subjectivity as a mode of interdependence that does not rely on a fixed essence. However, using Levinas for educational theory and practice by adopting and 'importing' his radical reevaluation of the philosophical standing of the subject leads to a position that is overly 'subjective' in a specific sense: namely by narrowing education to the attempted interruption of normal ('immanent') existence through teaching, which the teacher hopes will result in the 'awakening' of individual pupils or students qua subjects (Biesta 2017, 15). Taking a closer look at the example of the dying friend, it becomes clear what the problem with this line of reasoning is. Irreplaceability is formed in this case in a private environment, very close to specific individuals. For this reason, it is immediately clear when they are called upon. However, in the context of the problems facing education today such moral clarity is mostly not on offer. Consider the aforementioned climate and refugee crises. One consequence of the complexity of these kinds of problems is that it is not clear who is in charge when addressing them. These problems are almost the mirror image of the line of reasoning based on Levinas. First of all, day-to-day life can be lived as if nothing had happened (immanent existence might be interrupted, but is not necessarily experienced as such, at least not in the short term), and the call can be delegated to someone else (I am not called out as a unique subject). These larger topics often lead to questions such as: why should I be the one addressing this, and what can I do about it? It is not clear who bears responsibility, or that one is irreplaceable. This contrasts with the dying friend example where it is clear who should show up and what should be done. It is exactly within this ambiguous situation that subjectivity, and in the case of education subjectification, enters the domain: in taking the responsibility when someone else could have done it as well, in taking action oneself when other actions would have been possible, in order to create the world anew in a specific way. It is also here that action-as defined by Arendt-enters the educational stage. Subjectification in an educational setting is about rearticulating one's positions towards a shared world.

Crucial for our return to Arendt is the way she positions education. 
"Education is the point at which we decide whether we love the world enough to assume responsibility for it and by the same token save it from that ruin which, except for renewal, except for the coming of the new and young, would be inevitable. And education, too, is where we decide whether we love our children enough not to expel them from our world and leave them to their own devices, nor to strike from their hands their chance of undertaking something new, something unforeseen by us, but to prepare them in advance for the task of renewing a common world" (Arendt 1961, 196).

Education for Arendt is characterized by a type of double-bind: the responsibility for the world it opens us up to concerns renewal. Yet this renewal can only take place if a connection to the world is made first: that is, to the world as it currently exists. Moreover, setting the outcomes of education in advance would strike from the hands of newcomers 'their chance of undertaking something new': this would mean to fill in the blanks for the next generation in advance, thus not really doing justice to the nature of what comes 'next'. This argument is in line with Biesta's critique on critical pedagogies.

We also want to stress that in our reading of Arendt action is 'held up' by the two prior elements of the vita activa, labour and work. ${ }^{1}$ She repeats the same point in the first passage on education quoted above: the task of renewing a common world (through action) is premised on being prepared 'in advance', which in turn requires not being expelled from the world and not being left to one's own devices. What is this but the recognition that in order to renew the world, one must become part of it first? 'World' is here a technical notion which points out several requirements of action. Action is one of the three modes that jointly constitute human activity or vita activa. The world that action articulates and renews is not the material earth, but the product of work, that is our shared human world of man-made objects. Work in turn relies on labour, which is the circular activity of "animal laborans who inhabits the earth" (Arendt 1998, 40). Through action, we bring about a 'second birth' in our appearance on the public stage. We have already seen Arendt remark that "the essence of education is natality, the fact that human beings are born into the world" (Arendt 1961, 174). Natality is associated with the novel element introduced by each human being. Action requires work, which requires labour; assuming responsibility for the world by allowing it to be renewed by the newcomers (action) requires "educating for a world that is or is becoming out of joint" (ibid, 192). It is important to note that, in stark contrast to Levinas and Biesta, action is indeed 'active'; for the purposes of education, we can state that action concerns the initiatives of individuals, where what they initiate introduces something new into the world.

How this novelty will affect the world cannot be determined beforehand; it is clear that there are several ways for natality to be expressed. For this reason, we offer the possibilities of education as an alternative to Biesta's impossibility of education.

\footnotetext{
1 Biesta (2015b, CH6) undertakes an additional criticism of Arendt on the grounds that she of makes education 'developmental' and preparatory to politics; in that sense, education is outside of politics for Arendt, education being the proper domain of children and politics of adults. We cannot address this critical point fully here. It is true, to grant part of Biesta's point, that Arendt makes use of a quite uncritical distinction between adults and children in her text, and he correctly points out the problems such an approach faces. Yet there is also a phenomenological insight in Arendt's separation that is of use to thinking about education. One dimension of this insight concerns the world-relatedness of education: we have to understand the world as it is first in order to then rearticulate and thus change it. This is a similar point to Arendt's notion of action requiring the world fashioned by work and, in turn, the earth as the sphere of labor (see also Noordegraaf-Eelens et al. 2019).
} 


\section{Education as Taking Responsibilities}

How does this rebuttal to Levinas and Biesta affect education? We will discuss implications along two lines. The first line is about the relationship between interruption and responsibility, the second line is about the relationship between education and a shared world.

In the example that Biesta provides the relationship between interruption and responsibility is immediate and for that reason unambiguously clear. However, in a substantial number of current larger issues such moral clarity is absent. The interruption might not be felt and/or it is not clear who has to take responsibility, furthermore it can also be hard-if at all possible - to determine what the consequences of taking responsibility are. For example: in what way does the division of a single individual's waste contribute to the reduction of global temperature? The responsibilities we face are in many cases not at all clear-cut and in taking on such responsibility, we should ask how students and educators position themselves with respect to this situation. Consequently, to a large degree, responsibility in an educational setting is not something that one cannot help but take on after being called upon; rather, responsibility is something one takes on actively. This leads us to the question why we should make ourselves responsible, or act as responsible beings. The answer to this question is related to subjectification. It is in making ourselves responsible that we can position ourselves in a shared world (Noordegraaf-Eelens et al. 2019). Based upon available knowledge - gained through socialisation and qualification-new knowledge and new positions can be explored. The plural positions is important; multiple positions are possible. Instead of the predetermined possibility of transformation proposed by Freire or the impossibility of education conceptualized by Biesta, there are in fact possibilities of education, and within each possibility students and teachers can articulate their positions.

This contrasts with Levinasian responsibility, which requires an external appeal that casts aside all doubt. Once, in the Lingis example, my friend requests to see me, I know what needs to be done and more importantly that I am the one to do it. The relation of appealer and recipient of the appeal creates its own logic that manifests itself directly, which explains the 'hostage' language Levinas invokes (e.g.: "subjectivity is being a hostage", Levinas 1981, 127). Taking responsibility in our sense, is not about being-taken-hostage but about actively involving oneself. Insofar as subjectification concerns an exceeding of existing orders, going beyond the given in this way seems positively required. We are not in fact hostages of the situation but choose to act.

When we apply this to educational settings a shift takes place. While currently educational institutes determine what can be found on the curriculum, there should be room for students to take action. So, while institutions might have a say in the qualification and socialization parts of education, subjectification-since it concerns the active taking-on of responsibilities - asks for students who point out which topics they want to address, what according to them are the topics to be addressed. Of course, their topics are not the only ones available, but that is exactly the point. Students put topics on the agenda, and they practice justifying these topics and answering the why-question in educational settings: why do they think these topics should be addressed-why are these our responsibilities? Here we merely offer this question as a vista on the type of educational practice that our use of Arendt would entail. We thus move from Biesta's 'What do you think of it?' (Biesta $1998,2008)$ to asking students to justify their responsibilities in and towards the world. 
According to Biesta, education is not about fulfilling the (already present) desires of students, but about reflecting on what is desirable (Biesta 2019, 17). We think something similar can be said about responsibility. Education is not only about being made responsible in situations that are already morally clear — as a Levinasian account suggests—but also concerns taking responsibility in situations that are not. These responsibilities will be reflected upon and reformulated in education. And it is exactly in taking responsibility that one becomes unique, namely as the starting point of one's own action. It is through the active taking-on of responsibilities that subjectification takes place.

The second line of thought concerns the positioning of the shared world in education. The gap between Biesta's Levinasian subject and Arendt's world reflects an underlying rift that concerns the twin dimensions of responsibility and what one might call open-endedness, both relative to education. For Biesta, the educator carries a certain responsibility for her students, and because of the sheer depth of this "responsibility without knowledge" (for we are even responsible for what we cannot possibly foresee) (Biesta 2005) all she can do in the end is ask her students what they think. This makes education as a whole radically open-ended. As Biesta himself notes, the last thing one could do with this approach is derive an educational program from it (Biesta 2008). In fact, nothing can be done to compromise the (budding) subjectivity of the students. For this reason, Biesta's remark that he understands human subjectivity as "always understood as being-in-responsible-relation with other human beings and, by extension, with the natural world more generally" (Biesta 2019, 15; emphasis in original) fails to convince. The central educational task of subjectification is concerned precisely with human subjectivity and the world at large appears only as an additional clause. For Arendt, on the other hand, the responsibility of the educator primarily concerns the world and its renewal. Biesta finds an ally in Arendt because she, too, advocates for open-endedness and not striking from the newcomers' hands "their chance at the new" (Arendt 1961, 177). In other words, we cannot pre-empt the renewed world: we must leave its renewal to the newcomers themselves. But in Arendt, this openendedness exists only because we must renew the world in order for it to be maintained. Thus, for her it is not subjectivity as such, but the world held in common that cannot be compromised. In arguing for a return to Arendt, we are thus committed to the primacy of the world over Levinasian subjectivity.

In closing we want to offer two brief arguments to support this commitment. First, the continued existence of the world is the material precondition for any responsibility on the part of the educator. In our time our shared world faces severe challenges, so that education's essential reference to the world cannot be taken for granted and should in fact be of central educational concern. Second, granting primacy to Levinasian subjectivity only allows us to engage those problems that confront us in an immediate fashion. We have argued in previous sections that this entails an inability to engage with complex social issues of today. Moreover, if Levinasian subjectivity only responds to what confronts us in immediate fashion, so that we are reduced to hostages (in Levinas' expression), this seems to us to paint a limited picture of what subjectivity entails. Subjectification as theorized by Biesta concerns a subject that is able to act in excess or "'outside" of the given social orders $(2012,13)$. Starting from Levinasian subjectivity simply trades in obedience to social orders to an obedience to what is phenomenologically given - the 'call' to which we are forced to respond. In order to overcome the ensuing passivity in the face of what is given and to act in excess of it, we must incorporate the dimension of actively taking responsibility. Only by insisting on action can we do justice to the possibilities of education. 


\section{Conclusion}

In this article we discussed the shift in Biesta's work from subjectivity defined by Arendt to subjectivity defined by Levinas. This shift has significant consequences for how education is envisioned. From being active an educational setting becomes passive, or at most reactive. We argue for a return to Arendt. In her work, the connection between subjectivity and education revolves around concern for a shared world. This contrasts with a Levinasian approach that runs the risk of becoming overly subjective, thereby only addressing situations characterized by moral clarity. While these situations are important, education has more to offer. Arendt's approach is suitable for education in current times as students need to be prepared to address complex societal issues where responsibilities are not clearly allotted. Education can become the place where students can practice with the consequences of acting as unique individuals by taking responsibilities for a shared world.

Open Access This article is licensed under a Creative Commons Attribution 4.0 International License, which permits use, sharing, adaptation, distribution and reproduction in any medium or format, as long as you give appropriate credit to the original author(s) and the source, provide a link to the Creative Commons licence, and indicate if changes were made. The images or other third party material in this article are included in the article's Creative Commons licence, unless indicated otherwise in a credit line to the material. If material is not included in the article's Creative Commons licence and your intended use is not permitted by statutory regulation or exceeds the permitted use, you will need to obtain permission directly from the copyright holder. To view a copy of this licence, visit http://creativecommons.org/licenses/by/4.0/.

\section{References}

Arendt, H. 1961. Between past and future: Eight exercises in political thought. New York: Penguin Books.

Arendt, H. 1998. The human condition, 2nd ed. Chicago: University of Chicago Press.

Bauman, Z. 1993. Postmodern Ethics. Oxford: Blackwell.

Benhabib, S. 2018. Exile, statelessness, and migration: Playing chess with history from Hannah Arendt to Isaiah Berlin. Princeton: Princeton University Press.

Biesta, G. 1998. Say you want a revolution... suggestions for the impossible future of critical pedagogy. Educational Theory 48(4): 499-510. https://doi.org/10.1111/j.1741-5446.1998.00499.x.Biesta2005.

Biesta, G. 2005. Against learning. Nordisk Pedagogik 25(1): 54-66.

Biesta, G. 2008. Pedagogy with empty hands: Levinas, education, and the question of being human. In Lévinas and education (pp. 210-222). New York: Routledge.

Biesta, G. 2012. The future of teacher education: Evidence, competence or wisdom? RoSE-Research on Steiner Education 3(1): 8-21.

Biesta, G. 2015a. Good education in an age of measurement: Ethics, politics, democracy. Routledge.

Biesta, G. J. 2015b. Beautiful risk of education. Routledge.

Biesta, G. 2017. The rediscovery of teaching. London and New York: Routledge.

Biesta, G. 2019. Obstinate Education: Reonnecting school and society. Leiden \& Boston: Brill Sense.

Levinas, E. 1981. Otherwise than Being or Beyond Essence (transl. A. Lingis). Boston: Martinus Nijhoff.

Levinas, E. 1998. Entre Nous: Thinking-of-the-other (trans. M. Smith \& B. Harshav). London/New York: Columbia University Press.

Lingis, A. 1986. Phenomenological explorations. Dordrecht: Martinus Nijhoff.

Lingis, A. 1994. The community of those who have nothing in common. Bloomington and Indianapolis: Indiana University Press.

Noordegraaf-Eelens, L., J. Kloeg, and G. Noordzij. 2019. PBL and sustainable education: Addressing the problem of isolation. Advances in Health Sciences Education. https://doi.org/10.1007/s10459-01909927-z.

Rancière, J. 1991. The ignorant schoolmaster. Stanford: Stanford University Press.

Publisher's Note Springer Nature remains neutral with regard to jurisdictional claims in published maps and institutional affiliations. 